Authors' copy. For citation, please refer the published version. Kumpu Ville. (2016). On making a big deal. Consensus and disagreement in the newspaper coverage of UN climate summits. Critical Discourse Studies 13(2), 143-157.

\author{
Ville Kumpu
}

\title{
On making a big deal. Consensus and disagreement in the newspaper coverage of UN climate summits
}

\begin{abstract}
This article takes part in the discussion of the post-politicization of climate change by studying how consensus and disagreement were articulated in the coverage of four UN climate summits in the Finnish newspaper Helsingin Sanomat. From the perspective of discourse theory and an agonistic theory of democracy, the article argues that the hegemonic articulation of consensual politics, solving the problem of climate change, and establishing an international treaty on emission reductions to a chain of equivalence have reduced the field of disagreement to a choice between solving and not solving climate change. While such a form of hegemony represses more radical forms of political discourse, it is often considered helpful in building the consensus that is seen as a prerequisite for decisive action on climate change. This article argues that in building a durable relationship regarding climate change, political conflicts should be embraced in the name of democratic politics rather that suppressed in the name of generating and sustaining consensus.
\end{abstract}

Keywords: Journalism, climate change, climate summits, discourse theory, post-politics

The idea that a wide-ranging consensus reached through rationality is a prerequisite for decisive action is deeply embedded in climate change debates (Machin, 2013). From this perspective, disagreements in both climate science and climate politics appear as hindrances that forestall solving the issue often referred to as the greatest challenge of our time. The politicization of the climate change debate is reduced to an unwanted conflict between an enlightened set of people who understand climate science and the moral imperative it entails and are willing to act and a group of climate sceptics that question mainstream climate science or are unwilling to curb climatic change. This article departs from such understanding of climate politics and argues that, in building a durable relationship regarding climate change, disagreements and conflicts should be embraced rather than suppressed or downplayed in the name of reaching a consensus.

According to the agonistic theory of democracy, conflicts, disputes and disagreements are a constitutive feature of democratic politics and their absence is not a sign of political maturity, but rather a symptom of a void that can endanger democracy (Mouffe, 2005a, 2005b, 2013). 
From the perspective of agonistic theory, the political consensus, though assumed as a horizon in the deliberative theory of democracy (Habermas, 1984, 1987), can be used to suppress political differences and to marginalize those who dissent. In relation to debates about climate change, the lesson of agonistic theory is that, although consensus at both local and global levels may be articulated as necessary to save the planet, it will also unavoidably be an expression of a hegemony that is open to challenge. The repression of conflicts in the name of building a potentially planet-saving consensus has the potential to disconnect climate politics from meaningful political conflicts. This feeds climate apathy rather than enabling decisive action to curb climate change.

According to Swyngedouw (2010, p. 225), the hegemonic understanding of climate politics as a means to reach a rational consensus that is needed to solve the issue 'expresses and sustains the deepening of a post-political condition'. Here, 'post-political condition' refers to 'politics in which ideological or dissensual contestation and struggles are replaced by techno-managerial planning, expert management and administration'. In their study, empirically exploring the post-politicization of climate change through focusgroup interviews, Berglez and Olausson (2014, p. 15) concluded that while the emergence of a consensual discourse on climate change in Sweden has made it possible for 'more or less everybody to "see", talk about, and in practical ways deal with climate change', it has also repressed more radical political discourse. According to the study, the ideological mainstreaming of climate discourse in Sweden was ultimately achieved through its integration into post-political capitalist structures.

This article takes part in the discussion of the post-politicization of climate change by studying how consensus and disagreement were articulated in the coverage of four UN climate summits in the Finnish newspaper Helsingin Sanomat. One prominent articulation of the moral imperative of climate change as demanding action beyond any political disputes was the joint editorial initiated by The Guardian and published during the 2009 Copenhagen climate summit in 56 newspapers across the world (for an analysis see Eide, 2012). From the perspective of a consensual understanding of climate politics, the role of journalism can be reduced to climate communication that aims to enlighten audiences in a way that facilitates creating and sustaining consensus on the issue. Such a position in relation to climate change has not been an uncommon starting point for research on the media construction of climate change (see Boyce \& Lewis, 2009; Eide \& Kunelius, 2012c). From this perspective, the media logic manifested in the news values and principles of professional journalism, such as objectivity or impartiality, have been seen as obstacles in the effective communication of the issue (Boykoff \& Boykoff, 2004, 2007). Instead of understanding media coverage of climate change as climate communication, this article examines the coverage of climate summits in relation to the ideal of a democratic process that calls for 'a vibrant clash of political positions and an open conflict of interests' (Mouffe, 2005a, p. 6). Here, the question of media logic is relevant particularly because emphasis on conflicts and drama is often mentioned as a prominent news value (Golding \& Elliot, 2000) and as one of the reasons why journalism understood as climate communication has failed to foster the emergence of consensus on the issue (Boykoff, 2007).

The immediate counterargument for journalism or journalism research that aims to scrutinize the moral imperative of climate change as one political claim among others and not as something that is beyond or above politics - is that it plays into the hands 
of climate scepticism. From the perspective of climate communication, the primacy given to conflicts in journalism or journalism research may be interpreted as endangering the tackling of the issue - or as 'fiddling while the planet burns' (Boyce \& Lewis, 2009, p. 3). This article argues that rather than the struggle for a rational consensus, it is disagreement that can invigorate climate politics and produce the collective action to tackle the issue. According to Mike Hulme (2009), it is not a lack of understanding of the climate threat's seriousness that prevents the finding of a solution for it, but rather the idea of a solution to climate change that prevents building a sustainable relationship with regard to it. In debates about climate change, the hegemony of universal and material claims deriving from climate science has created an expectation for a political solution of the same magnitude. This is a misinformed expectation that is bound to lead to disillusionment. The ability of human beings to change the Earth's climate system, like the changes that are already under way, is not going to disappear. The search for ever-grander solutions to problems deriving the ability to change the climate is not a sustainable way of coming to terms with it.

According to Hulme (2009), more attention should be paid to what climate change can do for us and what it is doing to us as a powerful idea and an expression of the human condition in the twenty-first century. This is as opposed to focusing solely on what we can do for the physical realities of climate change. Although, for anyone worried about climate change, abandoning the idea of one unified climate change trend in need of a single solution as the solid base from which to demand consensual politics may seem counterintuitive, such a reversal is pivotal in coming to terms with the issue. In the long run, a pluralistic understanding of climate change as a powerful idea that resembles a shifting mirror ball that scatters images to and from all directions is a more sustainable basis for climate politics than is the suppression of differences in the name of a consensus articulated as the only rational direction for climate politics (Machin, 2013).

This article follows Hulme's encouragement to explore the articulation of climate change without clinging to the idea of finding a solution. It does this by exploring the media coverage of UN climate summits, which are considered to be the hubs of current global climate politics. Identifying nodal points that structure the current climate debate and discourses that are absent, marginalized or silenced through that structuration is one means of paving the way for re-articulations that would reflect a more sustainable relationship with the issue. Furthermore, this kind of work is crucial for understanding positions manifested in the climate change discourse and potential positions that are not currently articulated. It helps to understand how media politicizes climate change: which kinds of horizons for political action are kept open and which are closed.

\section{Material, method and research questions}

This article analyses the Helsingin Sanomat's coverage of the climate summits in Bali (2007, 69 stories), Copenhagen (2009, 168 stories), Cancún (2010, 57 stories) and Durban (2011, 56 stories). In total, this includes 350 stories. ${ }^{1}$ The annual climate summits, officially known as Conferences of the Parties of the United Nations Framework Convention on Climate Change (UNFCCC), are the most significant nodal points in global climate politics. They force different kinds of actors, forms of knowledge and visions of the future into a compressed time-space, functioning as moments of visibility and exposure (Eide \& Kunelius, 
2012b; Urry, 2011). Climate summits are highly purposeful events: their aim, pursued mainly through concluding an international (climate) treaty, is to accomplish the objective of the UNFCCC. That objective is the 'stabilization of greenhouse gas concentrations in the atmosphere at a level that would prevent dangerous anthropogenic interference with the climate system' (UNFCCC, 1992, p. 9).

In an international comparison, Helsingin Sanomat's coverage of the four summits can be characterized as extensive (Eide \& Kunelius, 2012a, 2012b; Eide, Kunelius, \& Kumpu, 2010). The majority of the coverage consisted of news stories or reportage from the scenes of the summits, but in addition, 10 editorials, 34 columns or comments by journalists and 45 letters to the editor were published during the summits and included in the research material of this article. Helsingin Sanomat is the only daily newspaper in Finland that can claim national reach. In an international comparison, it can be described as 'semiserious' (Sparks, 2000), but in the context of Finland, it is the prestige daily newspaper in the country. Its views and editorial decisions are often echoed in other media. The paper invested substantially in covering the summits. It had one staff correspondent present in Bali and in Durban and three in Copenhagen. The correspondents contributed substantially to the coverage: $15 \%$ of all stories in the case of Bali, $37 \%$ in the case of Copenhagen and $32 \%$ in the case of Durban.

The analysis of the articulation of consensus and disagreement in Helsingin Sanomat's summit coverage that is the purpose of this study is grounded in material collected and research conducted by the MediaClimate network, which was established to study the coverage of climate summits across the world (Eide et al., 2010; Eide \& Kunelius, 2012a, 2012b). As a part of a comparative effort, the manifest content of the Helsingin Sanomat coverage was analysed quantitatively using a coding scheme that classified among other things the genre, size and location of the stories and the people quoted in the stories. In this article, the quantitative analysis of sources quoted in the coverage is put to use in identifying parties that were considered relevant in the articulation of consensus and disagreement in Helsingin Sanomat's summit coverage. The qualitative analysis presented focuses on consensus and disagreement for two reasons: First, recent studies on climate change, climate politics and climate journalism (Berglez \& Olausson, 2014; Boykoff, 2011; Giddens, 2009; Hulme, 2009; Swyngedouw, 2010; Urry, 2011) pointed towards interesting paradoxes in the articulation of consensus and disagreement. Second, from the perspective of earlier comparative work, Helsingin Sanomat's coverage of climate summits seemed extensive but politically particularly consensual (Kumpu \& Kunelius, 2010).

To determine how consensus and disagreement were articulated in the coverage, the material was analysed from a discourse-theoretical perspective deriving from the work of political theorists, Ernesto Laclau and Chantal Mouffe. While the key text elaborating the premises of the approach - Hegemony and Socialist Strategy (Laclau \& Mouffe, 1985) - is certainly not a methodological guide, it has since its publication inspired a wide range of secondary literature exploring the possibilities of how the approach and its concepts could be 'translated to a proper methodological toolkit to tackle empirical data' (Carpentier \& De Cleen, 2007, p. 280) in different fields, including media research (see Carpentier \& Spinoy, 2007; Dahlberg \& Phelan, 2011; Howarth, 1995; Howarth, Norval, \& Stavrakakis, 2000; Howarth \& Torfing, 2005; Jørgensen \& Phillips, 2002; Torfing, 1999).

Discourse theory is anti-essentialist: no pre-given, self-determining essence that is capable of fully determining the meaning of things is assumed. Reality can only be 
accessed through its construction as a discursive form within an unavoidably ideological system of representation (Torfing, 1999, p. 113). In relation to climate change, this means that the physical processes related to anthropogenic climate change do not define its signification or contain an undisputable, extra-discursive imperative that could be transferred directly to the terrain of the political. The moral imperative of climate change is a political claim, not something extra-discursive that is beyond or above politics. Within this general framework, the central concepts of discourse theory put to use in the analysis were articulation, discourse, nodal points, hegemonic practices, logic of equivalence and logic of difference.

According to Laclau and Mouffe $(1985$, p. 105) articulation is 'any practice establishing a relation among elements such that their identity is modified as a result of the articulatory practice'. All meaning is constituted through articulatory practices. Discourses are structured totalities that result from the articulation of elements. Articulation is based on exclusion: giving meaning to something through articulation necessarily means also giving a negative identity to all theoretically infinite possible meanings that are not articulated. According to the anti-essentialist starting point, discursive stability is achieved in articulation but can also be dismantled through articulation. In achieving stability, nodal points are central. They are privileged signifiers around which a particular discourse is structured and in relation to which other moments in that discourse acquire meaning (Jørgensen \& Phillips, 2002, p. 28; Laclau \& Mouffe, 1985, p. 112). Hegemonic practices are a form of political articulation that through constructing and stabilizing nodal points link together different identities into a common project (Howarth, 1998, p. 279). According to Laclau and Mouffe (1985, pp. 127-134) hegemonic order is constructed and sustained through a logic of equivalence and the creation of chains of equivalence: through this simplification of political space, different identities are made equivalent and opposed to another negative identity. Conversely, the logic of difference is based on expansion and on increasing the complexity of the political space through the breaking of existing chains of equivalence and incorporating the disarticulated elements in another discursive order.

\section{Climate change and climate summits in Helsingin Sanomat}

In Finland, environmental issues have in general been well recognized and merged with the mainstream political agenda since the emergence of the environmental movement in the 1970s. As a major environmental problem, climate change emerged in Finland in the late 1980s and the early 1990s (Lyytimäki, 2012; Suhonen, 1993). According to public opinion polls, the general public has been considerably worried about the issue, though in recent years the worry expressed in polls has been in decline. ${ }^{2}$ As a member of the European Union, Finland is committed to the internal burden of sharing cuts in greenhouse gas emissions as well as to other targets of climate politics.

In Helsingin Sanomat, the volume of climate change coverage was relatively stable from 1995 to 2003, after which there was a significant increase in coverage (see Figure 1). ${ }^{3}$ The period around 2006 and 2007 when the volume of coverage in Helsingin Sanomat reached its peak has been described as a time of 'climate hype' in Finland (Lyytimäki, 2011). The peak was followed by a steep decline in coverage, and by 2011, the volume of coverage was again at pre-peak levels. Climate summits have been steadily covered in Helsingin 


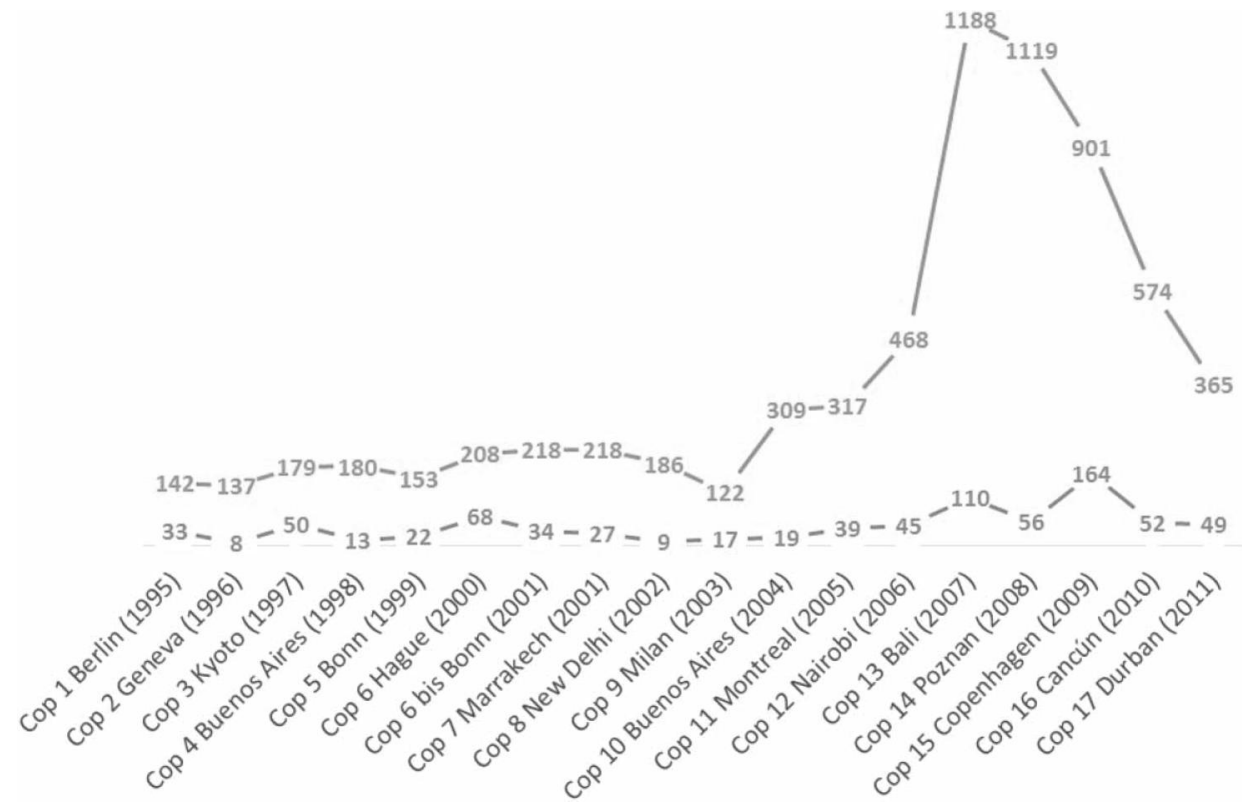

Figure 1. Climate change and climate summits in Helsingin Sanomat.

Sanomat (see Figure 1). The Bali and Copenhagen summits are two notable peaks (the latter against the general decline in climate coverage).

Two kinds of actors (in the form of directly or indirectly quoted individuals) dominated coverage of the four summits analysed in this article (Table 1): politicians representing nation states and civil society actors (representatives of environmental organizations, activists, demonstrators and people interviewed for vox pop pieces) comprised $68 \%$ of the actors. ${ }^{4}$ The former represented the more dominant share of actors, ranging from $47 \%$ (Bali) to $36 \%$ (Durban). The significance of politicians was further emphasized in news stories, particularly front-page stories, and as first actors in news stories. Climate (and other) scientists comprised $16 \%$ of actors quoted.

While keeping in mind that the material consists of stories from journalistic genres ranging from editorials to letters to the editor, it should be noted that a considerable part of the material did not quote anyone directly or indirectly (39\% of stories). Only 17\% (59 stories) had three or more actors. From the perspective of the quantitative study, the dialogue potential of the summit coverage does not seem too strong, given the fact that the most common combination of actors transcending the actor categories

Table 1. Actors quoted in the summit coverage of Helsingin Sanomat.

\begin{tabular}{lccccc}
\hline & $\begin{array}{c}\text { Bali (2007) } \\
(n=79)(\%)\end{array}$ & $\begin{array}{c}\text { Copenhagen (2009) } \\
(n=219)(\%)\end{array}$ & $\begin{array}{c}\text { Cancún (2010) } \\
(n=73)(\%)\end{array}$ & $\begin{array}{c}\text { Durban (2011) } \\
(n=75)(\%)\end{array}$ & $\begin{array}{c}\text { Total } \\
(n=446)(\%)\end{array}$ \\
\hline National political system & 47 & 39 & 29 & 36 & 41 \\
Transnational political system & 5 & 8 & 5 & 1 & 7 \\
Civil society & 19 & 30 & 22 & 33 & 27 \\
Business & 13 & 3 & 1 & 13 & 6 \\
Science, expertise & 14 & 16 & 34 & 16 & 16 \\
Other & 3 & 4 & 8 & 0 & 3 \\
\hline
\end{tabular}


was a politician representing a nation state and a civil society actor. This combination appeared in eight stories ( $2 \%$ of the material). Most commonly, a story included in the material quoted one politician (9\%) or one civil society actor $(8 \%)$. The most common combination within the actor categories was two politicians representing nation states (3\%).

In relation to the articulation of consensus and disagreement that is the focus of this article, the quantitative study indicates that in Helsingin Sanomat's coverage, the summits were understood as involving primarily politicians and secondarily NGOs and other civil society actors. Different kinds of actors were rarely mixed inside single stories; rather, they appeared in different kinds of stories within the coverage. From the perspective of the quantitative study, any disagreement in stories that was based on quoting was between politicians or between NGOs. Disagreement between these two major actor groups was either not articulated or articulated outside of single stories: between stories on the same page expressing differing views or stories on different days. The small number of (climate) scientists appearing in Helsingin Sanomat's coverage was also notable. Similar observations have been made in other studies, in which one of the reasons suggested for the infrequent quoting of climate scientists is their lack of PR resources compared to NGOs (Painter, 2010).

\section{Consensus and the horizon of solution}

It is by no means surprising that the idea of a solution to climate change in the form of an international treaty to reduce emissions would attain a central position in the journalistic coverage of an event that is focused exactly on crafting such a treaty. What is interesting (and what the analysis focuses on) is that, through the equation of the treaty with a solution to climate change, a situation was created whereby achieving a consensus that would enable establishing the treaty (thus solving climate change) became a nodal point that structured the articulation of disagreement. In Helsingin Sanomat's coverage, the horizon of a consensual solution to climate change was most forcefully articulated in editorials and in columns written by correspondents at the scene of the summits, which were published alongside the news coverage.

The editorial position of Helsingin Sanomat towards climate summits, the treaty and curbing climate change was sympathetic. The potential of the summits as world-saving moments deciding the future of the planet was highlighted repeatedly. Such articulation was sustained, despite the failure of the negotiations, in the editorials during all four summits.

This is the beginning of two years' work, and it is still possible to find a solution to slow down climate change - according to optimists even to stop the change. The unanimous will of the whole world is needed for that. ('USA enrolled in the making of a new climate treaty', 16 December 2007)

Despite all the hesitation, maneuvering and difficulties the negotiators have one great benefit at their side: a strong will to stop global warming. Everyone knows that if the Copenhagen summit fails, the climate will is going to wither and the window of opportunity will be lost. ('A world to be changed in two weeks', 6 December 2009)

However, the actualization of such treaty in the summit in South Africa next year requires a lot of work from the negotiators of different countries and also a genuine will to compromise on the part of both superpowers and developing countries. There is not a lot of time and the 
task is difficult, but not impossible. ('The agreement in Cancún was good climate news', 14 December 2010)

The summit at Durban was by no means useless, although tighter emission reductions targets were not achieved. Drafting a climate treaty that binds all countries in three years is a huge task but Durban provided some kind of a promise of that. ('Hope of a new treaty kindled in Durban', 13 December 2011).

The staff correspondents that Helsingin Sanomat sent to three of the four summits were important mediators of a climate will that both metaphorically and concretely enclosed the negotiations in the coverage. In columns published alongside the news coverage, the correspondents articulated a solution to climate change as a basis for consensual climate politics in a way resembling the paper's editorials. The need for a solution and consensus was highlighted by referring to the potential consequences of climate change in a way that reduced the future to a binary selection between no treaty (and, thus, the potentially devastating consequences of climate change) and a future defined by a treaty (and the continuation of business more or less as usual). ${ }^{5}$

Talk won't do it anymore. This Tuesday, indigenous peoples, whose lives are directly influenced by the warming of Arctic regions and the destruction of rainforests, presented their concerns in Copenhagen. For example, the whole basis for Inuit hunting culture is in danger of collapsing as Arctic ice melts [... ] The melting rate of glaciers and Arctic sea ice has accelerated. The sea level is projected to rise 30 centimeters in a hundred years. Developing countries dependent on agriculture are already suffering from heat, droughts and heavy rains. Coastal flooding has become more common in Finland. ('No time to hesitate', 9 December 2009)

With such catastrophic images of the future in view, the failure of the negotiations and the difficulties faced in reaching the desired consensus appeared unbelievable. Disappointment in the slow progress of the negotiations and problems identified in the arrangement of the summits were articulated in editorials and in columns from correspondents at the scene of the summits, especially after the Copenhagen summit. However, such criticism was always articulated in relation to a sustained hope for an agreement that could be reached through rational deliberation. One prominent example of such articulation was a correspondent's column where a parallel was drawn between climate negotiations and the discipline achieved in Finnish primary schools.

\footnotetext{
Meanwhile one has to take care of the team spirit that is in danger of falling apart at the seams, sooth scuffles that are breaking here and there and watch that naughty drawings will not appear on the blackboard when teacher turns her back. [...] If all that is achieved is a sloppy declaration of cooperation, it means a daily struggle over the same things. And the suggested two separate treaties? One half of the class agrees to wash their hands and the other to leave their coats on the coat rack. Even Finnish primary schools are able to outdo that. ('Teacher loses her temper', 18 December 2009)
}

In addition to writing columns highlighting the importance of consensual climate politics, the correspondents contributed substantially in writing news stories and reportage. In these stories, civil society, as articulated through NGOs, climate activists and people interviewed for vox pop stories, was a reference point from which the negotiations and the disagreements involved were interpreted. Especially in the case of the 2009 Copenhagen summit, the articulation of civil society's climate will was a prominent part of the coverage. A case in point was the climate march organized in the city that was reported as the central 
item on the front page and referred to as a 'good-humored public festival' (13 December 2009). The report continued inside the paper with a whole page assemblage of stories (with eight pictures of demonstrators and activists) celebrating the atmosphere and highlighting the demands made in headlines: 'Climate march demanded extensive action', 'The atmosphere here is unbelievable' and 'What message would you like to send from the Copenhagen demonstration?'

Civil society had a significant part in Helsingin Sanomat's summit coverage, both in terms of quoted sources and as a point of identification in the correspondents' news coverage. What was most important in relation to the topic of this article was that civil society, which had such a prominent position in the coverage, was articulated as a sphere of unanimity and consensus. In the coverage of the four summits, there was no attempt to identify disagreements between NGOs or climate activists over the issue of climate change; rather, the voices from civil society appeared virtually invariably as proponents of consensus and unanimity in order to achieve the treaty that would allow tackling of the issue. In relation to the media logic of covering summits, it is also worth noting that the representatives of different NGOs were almost exclusively Finnish people who had travelled to the summit site. In this sense, they were in a very similar position as Helsingin Sanomat's correspondents.

\section{Disagreement, doubt and resistance}

Disagreement was a major theme in news stories covering the actual negotiations. During the four summits, such coverage followed a similar script that began with a mixture of disagreement and hope, evolved into a political drama of differing views, and finally - usually after the official duration of the summit had been exceeded - turned into some form of unanimity or consensus, which was then presented as an important step towards the climate treaty. During this process, disagreeing parties, often presented as the 'key players' in the negotiations, were routinely identified and their motivations speculated upon. They included nation states (most notably the USA, China, Australia, Canada, Russia and India) or groups of nation states (e.g. the EU, 'industrialized countries', 'developed countries', 'developing countries', G77, 'poor countries', 'most vulnerable countries').

Despite its importance in news stories describing the negotiations, the disagreement articulated in relation to positions in the negotiations was embedded in a horizon of consensual climate politics in two ways. First, it constituted a distinct part of the coverage that was separated from issues ranging beyond the participants' motivation for a treaty. This was manifested clearly in the way other kinds of actors or voices were rarely articulated in the stories covering the negotiations. Second, in the coverage, the negotiations were evaluated from the perspective of a civil society unanimously demanding consensual politics to save the planet. Thus, any disagreement appearing in the negotiations was articulated as secondary in relation to a chain of equivalence between establishing a treaty and solving climate change. On the other hand, there was little effort made in the coverage to disrupt this configuration by breaking the chain of equivalence by highlighting the diversity of views and visions of the future inside it.

At the margins of the Helsingin Sanomat's summit coverage, some embryonic forms of disagreement, doubt and resistance to the hegemonic articulation of consensual politics did emerge. During the Copenhagen summit, a discussion in the letters to the editors 
section, sparked by the emails hacked from the Climate Research Unit at the University of East Anglia (often referred to as 'Climategate'), did contain moderately critical views of climate science and the negotiations. In caricatures, the summits were ridiculed by articulating an increase in tear gas emissions as an achievement of the Copenhagen summit (18 December 2009) and by drawing parallels between trying to solve the climate problem and flying to climate summits (4 December 2009). Beyond letters to the editors section and caricatures, there were two moments in the coverage where an attempt was made to break the hegemony of consensual politics. Symptomatically, both these moments were situated in other parts of the newspaper than its actual summit coverage.

The summit coverage of Helsingin Sanomat was completely disconnected from domestic politics. Based on the coverage, it would be impossible to say anything about the views of Finnish political parties about issues negotiated at the summits or the parties' views on climate change in general. In the four summits' coverage, there were only two or three instances when the summit discourse was clearly re-articulated in relation to domestic politics. The most prominent moment of such re-articulation was a story titled 'Parliament worried over the expenses of climate change for the poor' (3 December 2009) in which the expenses of climate aid were discussed in relation to domestic differences in income. Importantly, the initiative for such a re-articulation did not emerge from journalism but from a parliamentary discussion.

The other moment when a more pluralistic and conflictual view of climate politics emerged was connected to columns written by home desk journalists. In a stark contrast to the correspondents' comments mediating the climate will, in home desk journalists' columns, most prominent steps were taken to deconstruct it. In such columns, again published in other parts of the paper than the actual summit coverage, individual details and paradoxes related to climate summits or climate change, such as the relation between burning wood and carbon sinks or the false pride over meeting the Kyoto emission reduction targets, were critically scrutinized. ${ }^{6}$ The difference between columns written from the home desk and columns and news coverage emerging from the locations of the summits points to an interesting and empirically unexplored question on the effect that the proximity to the summits as mega events of climate activism has on journalists or, on the other hand, on the rationale behind sending a particular journalists to the summit site.

\section{The post-political condition of climate summits}

According to the analysis presented in this article, the idea of post-politicization of the climate change debate identified by Swyngedouw (2010) and Berglez and Olausson (2014) appears to accurately capture the logic underlying Helsingin Sanomat's coverage of four climate summits. The hegemonic articulation of consensual climate politics, solving the problem of climate change and establishing an international treaty on emission reductions to a chain of equivalence reduced the field of climate politics to the identities of solving and not solving. Such simplification is an important practice of hegemonic politics, but it is also a double-edged sword. On the one hand, it certainly helps to guard the issue from re-articulations in that any resistance or critical questioning can be articulated as not solving climate change. This makes it easy to speak for the treaty and highly burdensome to articulate critical positions. On the other hand, the attempt to deny 
re-articulations easily isolates the issue from meaningful political conflicts. This can lead the issue to lose its political relevance and lead to climate apathy rather than invigorate action to curb climate change.

From the perspective of the agonistic theory of democracy (see Mouffe, 2005a, 2005b, 2013) this article has argued that the consensual view of climate politics articulated in Helsingin Sanomat's summit coverage is based on an inadequate understanding of democratic politics. Agonistic theory underlines that consensus is not a viable horizon for climate politics because democratic politics are not a means to reach a consensus but based on disagreement; political differences should be embraced rather than suppressed, both in the present and in the future. The articulation of consensus as a prerequisite for solving climate change masks the political nature of the issue and works to secure the political status quo. The consensual view of climate politics protects the capitalist system which is the cause of climate change - from critical questioning because such criticism can readily be identified as disrupting the consensus so urgently needed to solve the issue (Berglez \& Olausson, 2014). In the context of the climate debate, it is 'easier to imagine the end of the world than to imagine the end of capitalism' (Jameson, 2003, p. 76).

In the case of Helsingin Sanomat's summit coverage, disagreement was an important part of the coverage, but it was articulated in a very limited form in relation to differing positions taken by nation states or groups of nation states in the negotiations. Furthermore, disagreements in the negotiations were articulated in relation to a global civil society unanimously demanding consensual politics to save the planet. The valuation of conflict in news discourse that is sometimes perceived as an obstacle to effective climate communication (Boykoff, 2007) was evident in Helsingin Sanomat's coverage only in relation to the negotiations. The paper made very little effort to actively politicize climate change by breaking the chain of equivalence between consensual climate politics, solving climate change and establishing an international treaty on the issue. A logic of difference enabling re-articulation of the issue in relation to topical disputes in domestic politics, for example, was not at play in the coverage. An interesting detail was the position of NGOs that certainly have the potential to articulate more radical positions in the climate debate - in relation to global justice, for example - but which appeared in the coverage as central mediators underlining the necessity of finding a consensus that would allow a climate treaty to be concluded. In a similar way, the critical potential of climate science was not used in evaluating and politicizing the summits but translated into a common sense that legitimized consensual politics.

As Berglez and Olausson (2014) note, there are certainly no simple answers to the question of how to ignite true democratic politics on issues such as climate change. According to the agonistic theory of democracy proposed by Mouffe (2005a, 2005b, 2013), the key task of democratic politics is to transform antagonisms, the us/them relations that constitute the political realm, into agonisms, relations in which political opponents are regarded as legitimate adversaries rather than enemies to be destroyed. If antagonistic relations are not seen in political terms, there is a danger that they can come to be captured in moral terms. It is crucial to understand climate change as a political issue rather than as a moral question because it is such articulation that foments democracy: passions about the environment and the climate can be mobilized, debate sparked and sustained and decisions between incommensurable options made (Machin, 2013). For climate change journalism, this suggests that the benevolent aim to educate audiences by communicating 
what climate change is and what it demands from us (exemplified by the summit coverage studied in this article) is flawed and potentially dangerous, as it easily identifies the climate debate as a moral choice between right and wrong instead of as a political confrontation. Rather than suppressing political confrontation, climate journalism should embrace it by identifying and articulating the political differences that democratic decisions are made of.

The post-political condition of climate change is affirmed by both the analysis of a Finnish newspaper's coverage of climate summits as presented in this article and the analysis of focus-group interviews with Swedish citizens presented by Berglez and Olausson (2014). Both studies explore the issue in similar contexts and at similar moments in the evolution of climate discourse. Sweden and Finland are both Nordic countries where climate awareness is high, but the issue is not politicized in any meaning of the word. Both studies are situated in a time period of high visibility of the issue in both countries. In Finland, this visibility has been identified in the climate coverage of Helsingin Sanomat during a period described elsewhere as a time of 'climate hype' (Lyytimäki, 2011). In Sweden, the situation has been described by Berglez (2011, p. 450) as a 'climate news boom'. Both studies point out that such high visibility has not resulted in struggles between the multiple interests and viewpoints involved; rather, it has been followed by climate apathy, in which people wait for the issue to be solved. To be sure, this Nordic version of the post-political condition of climate change is not the only way that it could figure in climate discourses around the world. More research on climate discourse from this perspective, particularly in contexts where the issue is politicized in some sense of the word, is needed. In relation to climate summits, the 2015 Paris conference will be an interesting case in point given that it has been advertised ${ }^{7}$ (much like the Copenhagen summit in 2009) as the climate summit of all climate summits, with a horizon of 'universal and meaningful climate change agreement' that 'can set our lives, our world, on course for a better future'.

\section{Notes}

1. The material was collected within the timeframe 1 December-22 December 2007/2009 (Bali and Copenhagen), 24 November-15 December 2010 (Cancún) and 23 November-14 December 2011 (Durban). It includes all journalistic material (including letters to the editor) published in print that concerned the summit or climate change in general. All combinations of title and text were considered as separate items (stories).

2. In a national survey commissioned by the Finnish business policy forum (EVA), a pro market policy think tank, in 2006, 86 per cent of the respondents agreed (fully or somewhat) with the statement 'climate change is the greatest threat of our time and action to prevent it should be taken immediately in all countries'. In 2004, the corresponding figure was $79 \%, 66 \%$ in 2010 , and $71 \%$ in 2012 . (Haavisto 2010, 2012). In a poll commissioned by Helsingin Sanomat, $82 \%$ of the respondents rated climate change as a 'great' or 'reasonably great' threat in 2007 while in 2009, the corresponding figure was 63\% (Helsingin Sanomat 15 September 2010: 'Worry over climate has faded').

3. Figure 1 is based on a keyword search of the electronic archive of Helsingin Sanomat. Keywords 'ilmastonmuutos' (climate change) and 'ilmaston lämpeneminen' (global warming) 
were used. The search was performed on 2 May 2012 and it includes all journalistic material (including letters to the editor) published in the print version of the paper. In the search results, every combination of title and text was considered as a separate item. In the case of the volume of summit coverage presented in Figure 1, the keywords used were 'ilmastonmuutos' (climate change), 'ilmaston lämpeneminen' (global warming) and 'kasvihuoneilmiö' (greenhouse effect) and the timeframe used was three days before and three days after each summit.

4. All individuals quoted directly or indirectly in the Helsingin Sanomat coverage were classified into five main categories and 26 sub-categories according to their 'institutional background'. The main categories were 'national political system' (representing a particular nation state), 'transnational political system' (e.g. the EU, the UN), 'civil society' (NGOs, activists, citizens), 'business' (e.g. entrepreneurs) and 'science and expertise' (e.g. climate scientists). The quantitative study of the material was conducted by the author of this article between 2009 and 2012. For details of quantitative study, see Eide, Kunelius and Kumpu (2010) and Eide and Kunelius (2012a).

5. For a detailed analysis on the articulation of future in the summit coverage, see Kumpu (2013) and Kumpu and Rhaman (2012).

6. 'A solution to climate change that is too easy' (22 December 2009), 'EU spells trouble' (4 December 2007), 'Oras Tynkkynen yearns for wind power instead of assumptions' (3 December 2009), 'The emission reduction targets of Helsinki are too modest' (7 December 2009), 'A problem with carbon sinks, at the micro level' (7 December 2009), 'Bargain politics for climate' (10 December 2009), 'Burning wood is not without emissions' (11 December 2009), 'Burning stumps is a sin after all' (3 December 2010).

7. Statement by United Nations Secretary-General Ban Ki-moon at the World Economic Forum 23 January 2015: http://www.un.org/sg/statements/index.asp?nid=8347.

\section{References}

Berglez, P. (2011). Inside, outside, and beyond media logic: Journalistic creativity in climate reporting. Media Culture and Society, 33(3), 449-465.

Berglez, P., \& Olausson, U. (2014). The post-political condition of climate change: An ideology approach. Capitalism Nature Socialism, 25(1), 54-71.

Boyce, T., \& Lewis, J. (2009). Climate change and the media: The scale of the challenge. In T. Boyce \& J. Lewis (Eds.), Climate change and the media (pp. 3-16). New York, NY: Lang.

Boykoff, M. (2007). From convergence to contention: United States mass media representations of anthropogenic climate change science. Transactions of the Institute of British Geographers, 32(4), 477-489.

Boykoff, M. (2011). Who speaks for the climate? Cambridge, MA: Cambridge University Press.

Boykoff, M., \& Boykoff, J. (2004). Bias as balance: Global warming and the US prestige press. Global Environmental Change, 14, 125-136.

Boykoff, M., \& Boykoff, J. (2007). Climate change and journalistic norms: A case-study of US massmedia coverage. Geoforum, 38, 1190-1204.

Carpentier, N., \& De Cleen, B. (2007). Bringing discourse theory into media studies. Journal of Language and Politics, 6(2), 265-293.

Carpentier, N., \& Spinoy, E. (Eds.). (2008). Discourse theory and cultural analysis: Media, arts and literature. Cresskill: Hampton Press.

Dahlberg, L., \& Phelan, S. (Eds.). (2011). Discourse theory and critical media politics. Basingstoke: Palgrave Macmillan. 
Eide, E. (2012). An editorial that shook the world ... global solidarity vs. editorial autonomy. In E. Eide \& R. Kunelius (Eds.), Media meets climate: The global challenge for journalism (pp. 125-144). Göteborg: Nordicom.

Eide, E., \& Kunelius, R. (Eds.). (2012a). Media meets climate: The global challenge for journalism. Göteborg: Nordicom.

Eide, E., \& Kunelius, R. (2012b). Moment of hope, mode of realism. International Journal of Communication, 6, 266-285.

Eide, E., \& Kunelius, R. (2012c). Introduction. In E. Eide \& R. Kunelius (Eds.), Media meets climate: The global challenge for journalism (pp. 9-28). Göteborg: Nordicom.

Eide, E., Kunelius, R., \& Kumpu, V. (Eds.). (2010). Global climate - local journalisms. A transnational study on how media make sense of climate summits. Bochum: Projekt Verlag.

Giddens, A. (2009). The politics of climate change. Cambridge, MA: Polity Press.

Golding, P., \& Elliot, P. (2000). News values and news production. In P. Marris \& S. Thornham (Eds.), Media studies: A reader (pp. 632-644). New York, NY: New York University Press.

Haavisto, I. (2010). Työelämän kulttuurivallankumous. EVAn arvo- ja asennetutkimus 2012. Yliopistopaino: Helsinki.

Haavisto, I. (2012). EU vai ei? EVAn arvo- ja asennetutkimus 2012. Taloustieto: Helsinki.

Habermas, J. (1984). The theory of communicative action. Vol. 1, Reason and the rationalization of society. Boston, MA: Beacon Press.

Habermas, J. (1987). The theory of communicative action. Vol 2, Lifeworld and system: A critique of functionalist reason. Cambridge, MA: Polity Press.

Howarth, D. (1995). Discourse theory. In D. Marsh \& S. Gerry (Eds.), Theory and methods in political science (pp. 115-133). Basingstoke: Macmillan Press.

Howarth, D. (1998). Discourse theory and political analysis. In E. Scarbrough \& E. Tanebaum (Eds.), Research strategies in the social sciences (pp. 268-293). Oxford: Oxford University Press.

Howarth, D., Norval, A., \& Stavrakakis, Y. (Eds.). (2000). Discourse theory and political analysis: Identities, hegemonies and social change. Manchester: Manchester University Press.

Howarth, D., \& Torfing, J. (Eds.). (2005). Discourse theory in European politics: Identity, policy and governance. Basingstoke: Palgrave Macmillan.

Hulme, M. (2009). Why we disagree about climate change: Understanding controversy, inaction and opportunity. Cambridge, MA: Cambridge University Press.

Jameson, F. (2003). Future city. New Left Review, 21, 65-79.

Jørgensen, M., \& Phillips, L. (2002). Discourse analysis as a theory and method. London: Sage.

Kumpu, V. (2013). A climate for reduction? UN climate summits as a context for imagining futures in journalism. Futures, 53, 53-62.

Kumpu, V., \& Kunelius, R. (2010). Finland: Coming to terms with political realities? In E. Eide, R. Kunelius, \& K. Ville (Eds.), Media meets climate: The global challenge for journalism (pp. 179-193). Göteborg: Nordicom.

Kumpu, V., \& Rhaman, M. (2012). Futures of the implicated and the Bystander. Comparing futures imagined in the coverage of climate summits in Bangladesh and Finland. In E. Eide \& R. Kunelius (Eds.), Media meets climate: The global challenge for journalism (pp. 105-122). Göteborg: Nordicom.

Laclau, E., \& Mouffe, C. (1985). Hegemony and socialist strategy: Towards a radical democratic politics. London: Verso.

Lyytimäki, J. (2011). Mainstreaming climate policy: The role of media coverage in Finland. Mitigation and Adaptation Strategies for Global Change, 16(6), 649-661.

Lyytimäki, J. (2012). The environment in the headlines: Newspaper coverage of climate change and eutrophication in Finland. Helsinki: Edita Prima.

Machin, A. (2013). Negotiating climate change: Radical democracy and the illusion of consensus. London: Zed Books.

Mouffe, C. (2005a). The return of the political. London: Verso.

Mouffe, C. (2005b). On the political. Abingdon: Routledge.

Mouffe, C. (2013). Agonistics: Thinking the world politically. London: Verso. 
Painter, J. (2010). Summoned by science. Reporting climate change at Copenhagen and Beyond. Oxford: Reuters institute for the study of journalism.

Sparks, C. (2000). Introduction: The Panic over Tabloid News. In C. Sparks, J. Tulloch, \& B. Zelizer (Eds.), Tabloid Tales. Global debates over media standards (pp. 1-40). Lanham: Rowman \& Littlefield.

Suhonen, P. (1993). Environmental issues, the Finnish major press, and public opinion. International Communication Gazette, 51(2), 91-112.

Swyngedouw, E. (2010). Apocalypse forever? Post-political populism and the spectre of climate change. Theory, Culture \& Society, 27(2-3), 213-232.

Torfing, J. (1999). New theories of discourse: Laclau, Mouffe and Žižek. Oxford: Blackwell.

UNFCCC. (1992). United nations framework convention on climate change. Retrieved from http:// unfccc.int/essential_background/convention/items/6036.php

Urry, J. (2011). Climate change and society. Cambridge, MA: Polity Press. 